\title{
PROSES PENYEMBUHAN LUKA ULKUS DIABETIKUM DENGAN METODE MODERN DRESSING DIKLINIK MAITIS EFRANS WOUND CARE
}

\author{
Nadya Putri Nabila, Pauzan Efendi, Husni \\ Politeknik Kesehatan Kementerian Kesehatan Bengkulu, Jurusan Keperawatan, \\ Jalan Indragiri Nomor 03 Padang Harapan Bengkulu \\ Email:nadya17ylh@yahoo.com
}

\begin{abstract}
Abstrac: Diabetes mellitus (DM) is one of the most common chronic diseases experienced by the world population and ranks fourth cause of death in developing countries. Long-term complications of diabetes mellitus one of them is diabetic ulcer $(15 \%)$ and is the most cause $(85 \%)$ of amputation in patients with diabetes mellitus. Currently, more than 5,000 modern types of dressings are reported to be available to treat wounds, especially diabetic ulcers. To know the process of wound healing diabetic ulcer was done with the design of case study research with a sample of 2 people and this study was conducted for 4 weeks. The study was conducted at the Maitis Efrans Wound Care clinic in Bengkulu City. The result was obtained that the assessment of diabetic ulcer wounds before modern wound care on the respondents was a total score of 54 and the respondents two total score of 50 were stated wound regeneration. The healing process of the responder's second ulcers progressed, the total score of one respondent was 30 and the respondent two was 28. Respondents. Progress on the two respondents stated better influenced by wound healing factor that is, age factor.
\end{abstract}

Keywords: Modern dressing, healing process of diabetic ulcers

\begin{abstract}
Abstak: Diabetes mellitus (DM) adalah salah satu penyakit kronis yang paling banyak dialami oleh penduduk dunia dan menempati urutan keempat penyebab kematian dinegara berkembang. Komplikasi jangka panjang dari diabetes mellitus salah satunya adalah ulkus diabetikum (15\%) dan merupakan penyebab terbanyak $(85 \%)$ terjadinya amputasi pada pasien diabetes mellitus. Saat ini, lebih dari500 jenis modern dressing dilaporkan tersedia untuk menangani luka khususnya ulkus diabetikum. Untuk mengetahui proses penyembuhan luka ulkus diabetikum tersebut dilakukan dengan desain penelitian studi kasus dengan jumlah sample 2 orang dan penelitian ini dilakukan selama 4 minggu. Penelitian ini dilakukan di klinik Maitis Efrans Wound Care kota Bengkulu. Hasilnya didapatkan, bahwa pengkajian luka ulkus diabetikum sebelum perawatan luka modern pada responden satu total skor bernilai 54 dan pada responden dua total skor bernilai 50 dinyatakan luka beregenerasi (wound regeneration). Proses penyembuhan ulkus kedua responnden tersebut mengalami kemajuan, total skor akhir responde satu bernilai 30 dan responden dua bernilai 28 . Responden. Kemajuan pada responden dua tersebut dinyatakan lebih bagus dipengaruhi oleh factor penyembuhan luka yaitu, factor usia.
\end{abstract}

Kata Kunci : Modern dressing, proses penyembuhan ulkus diabetikum

Diabetes Mellitus (DM) salah satu penyakit kronis yang paling banyak dialami oleh penduduk dunia dan menempati urutan ke empat penyebab kematian di negara berkembang (WHO, 2013). Diabetes Mellitus (DM) merupakan salah satu kelompok penyakit metabolik yang ditandai oleh hiperglikemia karena gangguan sekresi insulin, kerja insulin, atau keduanya. Keadaan hiperglikemia kronis dari diabetes berhubungan dengan kerusakan jangka panjang, gangguan fungsi dan kegagalan berbagai organ, 
terutama mata, ginjal, saraf, jantung, dan pembuluh darah (ADA, 2012).

Data dari studi global menunjukan bahwa jumlah penderita Diabetes Melitus pada tahun 2011 telah mencapai 366 juta orang. Jika tidak ada tindakan yang dilakukan, jumlah ini diperkirakan akan meningkat menjadi 552 juta pada tahun 2030 (IDF, 2011). Diabetes mellitus telah menjadi penyebab dari 4,6 juta kematian. Selain itu pengeluaran biaya kesehatan untuk Diabetes Mellitus telah mencapai 465 miliar USD (IDF,2011).

International Diabetes Federation (IDF) memperkirakan bahwa sebanyak 183 juta orang tidak menyadari bahwa mereka mengidap DM. Sebesar $80 \%$ orang dengan DM tinggal di negara berpenghasilan rendah dan menengah (IDF, 2011). Pada tahun 2006, terdapat lebih dari 50 juta orang yang menderita DM di Asia Tenggara (IDF,2009). Jumlah penderita DM terbesar berusia antara 40-59 tahun (IDF, 2011).

Diabetes mellitus (DM) adalah suatu sindroma gangguan metabolisme dan ditandai dengan hiperglikemia yang disebabkan oleh defisiensi absolut atau relatif dari sekresi insulin dan atau gangguan kerja insulin (Greenspan et.al dikutip dari Rizal,2008). Menurut kriteria diagnostik Perkumpulan Endokrinologi Indonesia (PERKENI) tahun 2006, seseorang didiagnosa menderita Diabetes Mellitus jika mempunyai kadar glukosa darah sewaktu >200 mg/dl dan kadar glukosa darah puasa $>126 \mathrm{mg} / \mathrm{dl}$. Manifestasi klinis Diabetes Mellitus yang sangat khas adalah meningkatnya frekuensi berkemih (poliuria), rasa haus berlebihan (polidipsia), rasa lapar yang semakin besar (polifagia), keluhan lelah dan mengantuk, serta penurunan berat badan (Price, 2005).

Komplikasi jangka panjang dari diabetes melitus salah satunya adalah ulkus diabetik $(15 \%)$ dan merupakan penyebab terbanyak $(85 \%)$ terjadinya amputasi pada pasien diabetes melitus (ADA, 2007). Clayton dan Tom (2009) mengungkapkan bahwa komplikasi lanjut ulkus diabetik adalah infeksi kronis. Menurut The National Institute of Diabetes Digestive AND Kidney Disease, diperkirakan 16 juta orang Amerika Serikat diketahui mengalami diabetes dan jutaan diantaranya beresiko untuk mengalami diabetes. Dari keseluruhan pasien diabetes, $15 \%$ mengalami ulkus dikaki, dan $12-14 \%$ dari yang mengalami ulkus dikaki memerlukan amputasi (NIDDK, 2008).

International Diabetes Federation (IDF,2015) menjelaskan bahwa, prevalensi dengan penderita Diabetes Mellitus pada tahun 2015 adalah 415 milyar orang. Sedangkan menurut Sulistyowati (2015) memaparkan bahwa, untuk prevalensi penderita ulkus kaki diabetik sekitar 15\% dengan risiko amputasi $30 \%$, angka mortalitas 32\%, dan di Indonesia ulkus kaki diabetik merupakan penyebab paling besar untuk dilakukan perawatan di rumah sakit sebesar $80 \%$.

Menurut Purwanti (2013), bahwa di Indonesia terdapat 1785 penderita DM yang sudah mengalami komplikasi seperti, neuropati $(65,3 \%)$, retinopati $(42 \%)$, nefropati $(7,3 \%)$, makrovaskuler (16\%), mikrovaskuler (6\%), dan luka kaki diabetik (15\%) sedangkan angka kematian akibat ulkus kaki diabetik dan ganggren mencapaiu $17-23 \%$ serta angka amputasi mencapai $15-30 \%$, selain itu angka kematian 1 tahun pasca amputasi sebesar $14,8 \%$. Hal ini didukung oleh data Riskesdas (2013), bahwa kenaikan jumlah penderita ulkus diabetik di Indonesia dapat terlihat dari kenaikan prevalensi sebanyak $15 \%$.

Metode perawatan luka yang berkembang saat ini adalah menggunakan prinsip moisture balance,yang disebutkan lebih efektif dibandingkan metode konvensional. Perawatan luka menggunakan prinsip moisture balance ini dikenal sebagai metode modern dressing (Bowszyc, 2014). Penelitian lain juga menyatakan bahwa lingkungan yang lembab dapat mempercepat respon 
inflamasi, sehingga proliferasi sel menjadi lebih cepat (Bryant, 2007). Dalam suasana lembab metabolisme sel akan menjadi lebih baik karena tersedia air, nutrisi, dan vitamin lebih banyak.Efek suasana lembab dapat mencegah dehidrasi jaringan, kematian sel, mempercepat angiogenesis, meningkatkan pemecahan jaringan mati dan fibrin, serta mengurangi nyeri saat medikasi (Makoto, 2012).

Saat ini, lebih dari 500 jenis modern wound dressing dilaporkan tersedia untuk menangani luka. Bahan modern wound dressing dapat berupa hidrogel, film dressing, hydrocolloid, calcium alginate, foam absorbant dressing, antimicrobial dressing, (Geary, 2012 ).

Penggunaan perawatan luka dengan menggunakan modern dressing berkembang pesat dalam perawatan luka pada pasien diabetes (Sotani, 2009). Survey terhadap diabetes di Jakarta menunjukkan bahwa 1 dari 8 orang mengalami diabetes. Baik pria maupun wanita, tua maupun muda, tinggal di kota maupun di desa, memiliki risiko yang sama.

Sebagian besar rumah sakit di Indonesia masih menerapkan prinsip perawatan luka konvensional sebagai contoh sebanyak 30 rumah sakit di Surabaya, hanya ada 3 rumah sakit yang menerapkan metode penyembuhan luka dengan cara modern. Sedangkan di Indonesia, jumlahnya lebih sedikit lagi, dari total 1012 rumah sakit hanya 25 rumah sakit atau $2.4 \%$ yang menerapkan metode ini (Ismail, 2008). Perawatan konvensional dan modern memiliki perbedaan dan ciri khas masing-masing baik dalam teori, praktik, maupun kelebihan dan kekurangannya. Menurut Sing et.al (2011) menyatakan enam puluh persen dari kelompok modern dressing dalam merawat luka menunjukkan bersih dari organisme secara penuh dalam dua minggu, dan sekitar $90 \%$ dalam empat minggu meskipun hanya enam luka tidak menunjukkan bersih dari organisme di akhir minggu keempat. Di sisi lain, hanya $42 \%$ dari luka di kelompok konvensional ditemukan steril setelah dua minggu perawatan. Setelah empat minggu pengobatan konvensional 12 (20\%) luka masih ditemukan sekumpulan organisme patogen. Di Kota Bengkulu banyak masyarakat khususnya yang didiagnosa ulkus diabetikum belum mengetahui apa itu perawatan ulkus diabetikum dengan Metode modern dressing dan bagaimana proses perawatannya. Pada umumnya di Rumah sakit di Kota Bengkulu masih menggunakan Metode Konvensional.

Beberapa penelitian menunjukkan perawatan luka pada pasien ulkus diabetikum dengan menggunakan modern dressing sangat efektif, seperti penelitian Salia Marvinia Widaryati pada Januari tahun 2013 yang berjudul Efektifitas metode perawatan luka Moisture Balance terhadap penyembuhan luka pada pasien ulkus diabetikum di Klinik Perawatan Luka Fikes UMM Yogyakarta. Dimana hasil penelitiannya didapatkan kondisi luka sebelum dilakukan perawatan luka moisture balance didapatkan jumlah rerata 28,9 dan setelah dilakukan perawatan luka moisture balance didapatkan jumlah rerata 19,3. Hasil analisis menunjukkan 2,201, terdapat perbedaan yang signifikan anatara sebelum dan sesudah perawatan luka dengan teknik moisture balance pada pasien ulkus diabetikum. Dengan latar belakang masalah diatas bahwa prinsip perawatan luka dengan menjaga agar luka dalam keadaan lembab. Peneliti mencoba mengetahui bagaimana gambaran proses penyembuhan luka ulkus diabetikum dengan metode modern dressing di Klinik Maitis Efrans Wound Care Kota Bengkulu.

\section{BAHAN DAN CARA KERJA}

Penelitian ini dilakukan dengan menggunakan pendekatan kualitatif yaitu pendekatan penelitian tanpa menggunakan angka statistik tetapi dengan pemaparan secara deskriptif yaitu berusaha mendeskripsikan suatu gejala,peristiwa, 
kejadian yang terjadi menjadi faokus perhatiannya untuk kemudian dijabarkan sebagaimana adanya.

Metode yang digunakan adalah metode studi kasus sesuai dengan yang disampaikan oleh Yin (2008), studi kasus digunakan sebagai suatu penjelasan komprehensif yang berkaitan dengan berbagai aspek seseorang, suatu kelompok, suatu organisasi, suatu program, atau suatu situasi kemasyarakatan yang diteliti, diupayakan dan ditelaah sedalam mungkin.

\section{HASIL}
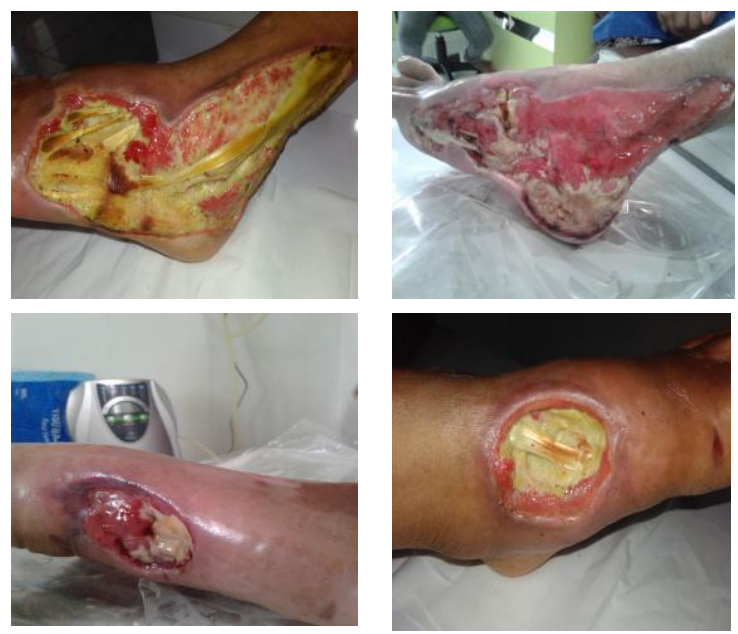

Hasilnya didapatkan bahwa ulkus diabetikum pada responden satu mengalami regenerasi yaitu dari kondisi awal sebelum dilakukan perawatan luka modern dengan total skor 54 dan pada kondisi akhir setelah dilakukan perawatan sebanyak 12 kali dengan total skor 30 dinyatakan luka berregenerasi dan responden dua kondisi awal sebelum dilakukan perawatan luka modern dengan total skor 49 dan pada kondisi akhir setelah dilakukan perawatan sebanyak 12 kali dengan total skor 28 dinyatakan luka berregenerasi (Wound Regeneration).

\section{PEMBAHASAN}

Berdasarkan hasil penelitian pada responden satu yang berumur 67 tahun didapatkan kemajuan proses penyembuhan ulkus diabetikum, dimana total skor awal 54 dan total skor akhir 30. Pada responden dua yang berumur 45 tahun didapatkan total skor awal 49 dan total skor akhir 28. Berdasarkan faktor penyembuhan luka salah satunya yaitu nutrisi, pasien dengan luka ganggren memerlukan diet tinggi protein, vitamin a, c, b12, zat besi, dan kalsium (Harman, 2007). Pemenuhan kebutuhan nutrisi untuk kedua responden terutama protein, selama proses perawatan dan penelitian ini pasien dianjurkan untuk mengkonsumsi putih telur sebanyak 6 butir/hari. Hal ini sesuai dengan hasil penelitian Cecep Triwibowo tahun 2015 mengenai Faktor-faktor yang mempengaruhi penyembuhan luka ganggren pada penderita diabetes mellitus di ruang rawat inap RSUD DR. Pirngadi Medan.

Hasil penelitian tersebut menunjukkan bahwa dari 20 responden paling banyak 14 orang $(70 \%)$ nutrisi yang terpenuhi yaitu dengan mengkonsumsi diet tinggi protein, vitamin A, C, B12, zat besi, dan kalsium dapat mengalami penyembuhan luka dengan kriteria sembuh. Penyembuhan luka membutuhkan dua kali lipat kebutuhan protein dan karbohidrat dari biasanya untuk segala usia. Diet seimbang mengandung bahan nutrisi yang dibutuhkan untuk perbaikan luka seperti asam amino ( daging, ikan dan susu), energi sel (bijibijian, gula, madu, buah-buahan dan sayuran), vitamin C ( buah kiwi, strawberry, dan tomat), vitamin A ( hati, telur, buah berwarna hijau cerah, dan sayur-sayuran), Vitamin B ( kacang, daging dan ikan), zinc (makanan laut, jamur, kacang kedelai, bunga matahari), bahan mineral (makanan laut dan kacang dari biji-bijian), air (Ekaputra, 2013). Faktor penyembuhan luka lainnya yaitu usia, pada responden dua kemajuan proses penyembuhan ulkus diabetikumnya lebih bagus dibandingkan responden 1 , hal ini dikarenakan usia responden termasuk masih bagus untuk proses penyembuhan ulkus diabetik. Hal ini sesuai dengan pendapat atau teori (Harman,2007) yang mengatakan bahwa usia anak sampai 
dewasa memiliki penyembuhan luka yang cepat daripada yang tua. Hal ini dikarenakan orang tua yang mengalami penurunan fungsi multi organ.

Kemajuan proses penyembuhan ulkus diabetikum pada kedua responden ini juga dipengaruhi oleh kadar gula darah responden. Gula darah responden satu selama proses perawatan didapatkan berkisar antara $180-300 \mathrm{~g} / \mathrm{dl}$. Sedangkan pada responden dua berkisar antara 197 $245 \mathrm{~g} / \mathrm{dl}$. Menurut teori, hiperglikemia (tingginya kadar gula) yang terus menerus mengakibatkan sirkulasi darah terutama pada kaki menurun, dengan gejala-gejala sakit pada tungkai bila berdiri, berjalan, atau melakukan aktifitas fisik, kaki terasa dingin dan tidak hangat. Sumbatan yang terjadi pada pembuluh darah sedang atau besar ditungkai kaki menyebabkan gangren diabetik yaitu luka pada kaki yang berwarna merah kehitam-hitaman, berbau busuk dan akibatnya terjadi kematian jaringan (Karyadi, 2002).

Ulkus diabetik pada kedua responden ini diukur dengan menggunakan pendekatan Bates-Jansen Wound Assesment Tool (BWAT). Proses perawatan luka ini kedua responden menggunakan Bahan modern wound dressing berupa : Pertama Foam Dressing, jenis sabun yang digunakan untuk mencuci luka tersebut adalah setelah diberi sabun luka tersebut dicuci dengan air rebusan daun jambu biji, lalu dikeringkan dengan menggunakan kassa steril. Setelah kering luka di bungkus dengan plastik untuk selanjutnya diberikan sinar ozon dan sinar Ultraviolet yang berfungsi untuk meminimalisir kuman-kuman pada luka tersebut. Selanjutnya dilakukan tindakan pembuangan jaringan nekrotik dengan menggunakan gunting jaringan dan pinset cirugis yang steril. Setelah bersih luka diberikan salep khusus untuk luka yaitu Metcovazin. Selanjutnya menggunakan Film Dressing, jenis film dressing yang digunakan yaitu $O p$-site. Ini digunakan pada perawatan ke-7 karena eksudat $<25 \%$ membasahi balutan. Kedua Hydrocolloid, jenis hydrocolloid yang digunakan yaitu Duoderm extra thin, dapat menjaga kestabilan kelembaban luka dan sekitar luka, menjaga dari kontaminasi air dan bakteri, bisa digunakan untuk balutan primer dan balutan sekunder. Ketiga Alginate, jenis alginate yang digunakan pada kedua responden ini adalah Kaltostat yang berguna untuk mengangkat jaringan mati.

Pada pasien dengan ulkus diabetikum membutuhkan perawatan jangka panjang untuk dapat sembuh kembali. Dalam penelitian Sheehan (2007), dilaporkan perawatan pasien dengan ulkus diabetikum akan menunjukkan penutupan luas area luka pada 4 minggu pertama dan sembuh total 12 minggu. Pada penelitian ini kedua responden telah menunjukkan kemajuan dalam proses penyembuhan ulkus diabetikum, dimana pada 12 kali perawatan luka yang berlangsung selama 1 bulan total skor yang didapat peneliti mengalami penurunan. Semakin tinggi nilai BWAT menunjukkan karekteristik luka semakin tidak baik begitu sebaliknya semakin kecil nilai maka proses penyembuhan luka semakin membaik. Hal ini sejalan dengan penelitian Ellisa Maharani (2015) yang berjudul Pengaruh teknik modern dressing terhadap proses penyembuhan luka diabetes melitus di klinik perawatan luka Griya Assyifa didapatkan hasil Ada pengaruh teknik modern dressing terhadap proses penyembuhan luka diabetes melitus di Klinik Perawatan Luka Griya Assyifa' Kabupaten Jember.

Kelemahan pada penelitian ini yaitu kurang bervariasinya umur pasien dan jumlah sample yang sedikit, sehingga memperoleh hasil yang kurang maksimal. Dengan umur responden yang bervariasi peneliti bisa melihat proses penyembuhan luka ulkus diabetikum berdasarkan faktor penyembuhan lainnya. 


\section{KESIMPULAN}

Berdasarkan hasil penelitian mengenai Gambaran proses penyembuhan ulkus diabetikum dengan menggunakan metode Modern Dressing di Klinik Maitis Efrans Wound Care Center Kota Bengkulu, dapat disimpulkan bahwa : Pengakajian luka ulkus diabetikum sebelum perawatan luka modern pada responden satu total skor bernilai 54 dan

\section{DAFTAR RUJUKAN}

Arisanty,Irma. 2014.Konsep Dasar: Manajemen Perawatan Luka. EGC: Jakarta.

Ekaputra, E. 2013. Evolusi Manajemen Luka. Jakarta: Trans Info Media.

Gitarja. 2000. Perawatan Luka Diabetikum. Edisi 2. Bogor. Wocare Publishing

Maryunani, A. (2013). Perawatan luka modern (Modern Wound Care) terkini dan terlengkap sebagai bentuk tindakan keperawatan mandiri. Jakarta: In Media.

Notoatmodjo, S. 2010. Metodologi Penelitian Kesehatan Jakarta: Rineka Cipta

PERKENI, 2011. Konsensus Pengelolaan dan Pencegahan Diabetes Melitus tipe 2 di Indonesia.

(http:ml.scribd.com/doc/73323977/Kon sesnsus-DM-Tipe-2-Indonesia-2011 pada responden dua total skor bernilai 50 dinyatakan luka berregenerasi (wound regeneration). Proses penyembuhan ulkus diabetikum pada kedua responden tersebut mengalami kemajuan, total skor akhir responden satu bernilai 30 dan responden dua bernilai 28. Responden dua mengalami prose penyembuhan ulkus diabetikum lebih bagus dibanding responden satu yang disebabkan oleh faktor usia.

RISKESDA, 2013. Riset Kesehatan Dasar Tahun 2013. Badan Penelitian dan Pengembangan Kesehatan Kementrian Kesehatan RI Tahun 2013.

Singh, A., Phratilba, E.M., Amrit, N., Prajanna, S., \& Nihal, T., 2011. Awareness and Attitude Towards Diabetes in the Rural Population of Arunachal Pradesh, Northeast, India. IJEM vol. $16: 83-86$

Smelltzer, S.C., Bare, B.G. 2001. Buku Ajar Keperawatan Medikal-Bedah Brunner \& Suddarth. Vol. 2. Edisi 8. Jakarta : EGC.

Suyono S. Diabetes Melitus di Indonesia. Buku Ajar Ilmu Penyakit Dalam. IV edisi Jakarta: Pusat penerbitan Ilmu penyakit dalam FK UI:2006 